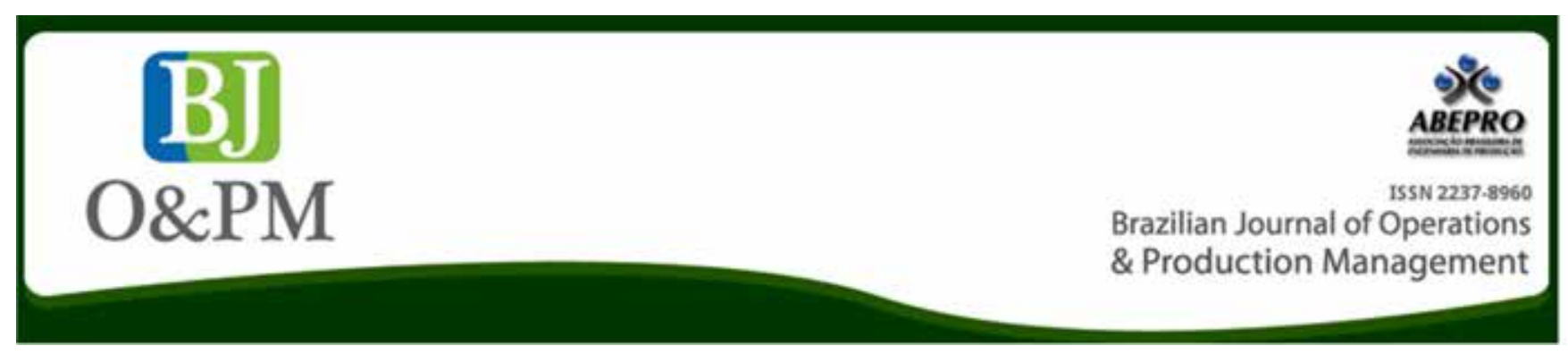

\title{
IDENTIFICATION AND PRIORITIZATION OF EFFECTIVE FACTORS ON THE CREATION AND DEVELOPMENT OF INDUSTRY CLUSTER OF RAIL INDUSTRIES USING NETWORK ANALYSIS TECHNIQUE
}

Reza Yadegari

msanayereza1@yahoo.com Department of Industrial

Management, Tabriz Branch, Islamic Azad University, Tabriz, Iran.

\section{Kamaleddin Rahmani}

kamaleddinrahmani@iaut.ac.ir Department of Industrial

Management, Tabriz Branch,

Islamic Azad University, Tabriz, Iran.

Farzin Modarres Khiyabani f.modarres@iaut.ac.ir Department of mathematics, Islamic Azad University, Tabriz branch, Tabriz, Iran.

\begin{abstract}
Increased productivity and new investment are two methods for the development of industry, and one of the differences between advanced industrial countries and developing countries is to pay particular attention to development through increased productivity. In recent years, new models have been developed in the industry sector, dating to less than fifteen years; one of them is the model of industrial cluster development. Industrial clustering is being carried out today in almost every country in the world. In Iran, the industrial cluster issue is considered in scientific and decision-making centers, as well as in the development plans of the country. The purpose of this research was to identify and prioritize the effective factors on the development and creation of industry cluster of rail industries in the Markazi Province using the network analysis technique. In order to identify cluster creation factors, library studies and the Delphi method were used with the cooperation of the expert group. In the following, we examined the relative importance of these factors using the network analysis technique and the factors were prioritized by Super Decision Application. The results showed that the indicators of geographical concentration and environmental factors are included in the most important factors and the communication index is the least important factor in the creation and development of industrial clusters of rail industries in the Markazi Province.
\end{abstract}

Keywords: Industrial Cluster; Rail Industries Development; Delphi Method; Network Analysis. 


\section{INTRODUCTION}

Alfred Marshall (1890), in the book Principles of Economics, mentions the accumulation of specialized industries in local areas as industrial clusters (Kuah, 2002). Industrial clusters are considered as one of the most important and successful industrial and regional development approaches and are considered by many policy makers in developed and developing countries. Here it is presented the different definitions provided for the cluster by different researchers, and then a functional definition will be found for the purposes of this research. Industrial cluster means the geographical concentration of small and medium enterprises that, in addition to having the common opportunity and threats, seek to complete their supply chain in that area (Mansouri, 2008).

A group of companies with strong vertical links in a region are not necessarily close to each other geographically (Porter, 1990). In its general concept, cluster refers to the spatial concentration of economic activity in a particular field. What makes clusters be considered in this way by policy-makers are the opportunities related to collective action, which result from external economy of scale, low transaction costs, and collective action. Thus, the mere special accumulation of companies that do not communicate with each other cannot increase collective performance. It is the interactions and external effects that are considered. Therefore, the cluster is a fairly large collection of economic enterprises that are within a certain spatial range; they have a distinct expertise background, and in terms of cluster, the inter-firm trade, and the expertise of the firms are remarkable (Altenburg and Meyer-Stamer, 1999). The industrial clusters of the accumulation of collaborative and rival industries in a networked area in the form of vertical and horizontal communications, including the joint and strong links between the buyer and the supplier, are expert economic institutions (Stimson et al., 2006). The development of the cluster depends on the factors of technology transfer, knowledge transfer, the development of skilled labor in the related industries, the benefits of a dense economy and social infrastructure. Porter attributes the development of the cluster to competition and focuses on how to compete through these key factors (Kumar, 2005).

The rail industry is an economic, sustainable, and economical industry. First of all, the cost of transportation in the rail sector is lower than that of other transport methods, and it has attracted the attention of all countries in the world. Secondly, during the years passed since industry development, rail industry has always been one of the considered industries that are being developed continuously, and there has been no alternative industry for it up to now. Considering the importance and necessity of the develop- ment of industrial cluster of rail industries, the aim of this research is to identify and prioritize the effective factors on the development of industrial cluster of rail industries in the Markazi Province.

\section{RESEARCH THEORETICAL LITERATURE}

\section{Creation and development of industrial clusters}

There are common things about how to establish and develop clusters in different countries and for various industries; however, there is no specific, general, and common model for establishing a global cluster that can be implemented in all the countries of the world. The creation of clusters is performed in two ways: spontaneously and systematically. Spontaneous clusters are those that have been established by spontaneous concentration of factors (Chiaroni and Chiesa, 2006). According to Yamawaki's findings (2002) regarding 37 industrial clusters in Japan, various factors will make the local industrial clusters be established and developed, including historical conditions, the existence of large former industries, the existence of supportive industries, the existence of related industries in the near geographic regions, the reduction of transport costs, regional governmental policies, and the transfer of technology and human resources. The existence of economic enterprises in the width and length of each other, the existence of a coordination linking national and local institutions, and the existence of regulations facilitating the communication have been the factors influencing the creation of industrial clusters. The cluster members and enterprises participate in the cluster. There is also competition within the cluster. This competition can be carried out in an advanced way among cluster members in the international markets. It should be noted that reducing competition among members is the most important goal of cluster development. The idea of reducing competition means assuring enterprises about more collaboration of the cluster to easily access a commercial production factor. The achievement of the above goals in the cluster will facilitate competition outside of the cluster, and prepare business companies of the clusters for international competitions (Kim, 2002). The clusters compete and promote collaboration. Competitors compete strongly in attracting and retaining customers.

The success of a cluster requires a serious competition. Nevertheless, there is also a partnership between them, which is usually vertical, and this partnership includes companies in the related industries and in-cluster institutions. Competition can be a symbiosis through collaboration because it has different dimensions and is made among different players and ultimately leads to development (Porter, 1998). 
Brazilian Journal of Operations \& Production Management

Volume 15, Número 4, 2018, pp. 490-498

DOI: 10.14488/BJOPM.2018.v15.n4.a3

\section{Industrial cluster of rail industries in the Markazi Province}

The cluster of the Arak rail industries is the largest rail industry in the Middle East and it can produce various types of rail products. The value added in the cluster was $\$ 47$ million, accounting for over $78 \%$ of the value added nationwide. Due to the lack of continuous production lines and production according to the order, the rail industry is considered one of the employment industries, and Arak city, as one of the major industrial centers, contributes significantly to the employment of the rail industry in the country. The rail industry workers in 119 industrial units of the central province are more than 11,000 people directly, and, taking into account the employment generated in other industries, they are more than 20,000 people (Agakhani, 2009).

The ability to build and increase production capacity in accordance with the market needs, the design and engineering capability at the cluster level in accordance with the market needs, the familiarity of large manufacturers and some middle-market producers with the market, the existence of a valid wagon-production brand and the possibility of competition in terms of price and the quality at the same time, the strategic geographical location of the cluster, the industrial context of the region, the ability to build or enhance the level of machinery and the ability to absorb new knowledge and technologies, the high level of innovation in the region, the availability of appropriate hardware, and the presence of skilled and trained human resources are some of the strengths of the cluster of rail industries in Markazi Province.

\section{Factors affecting the development of the industrial clus- ter of rail industries}

According to the regional information obtained from the field study and the Delphi method, using the open questionnaire and in-person interview with the various institutions involved in the research subject and study of the available resources, the most important goals of creation of an industrial cluster proportionally with the region were identified. Since some of these factors overlap, they are combined with each other and are defined in the form of six factors as general factors affecting the development of industrial clusters in a framework.

Accordingly, based on the research literature and the use of the Delphi method, six main factors affecting the industrial cluster are identified and are described in the following: (Table 1.)

1. Environmental factors index: The environmental factor is the potential of the area.

2. Demand conditions index: One of the components that are focused in Porter's famous model is the de- mand conditions that depend on the market. When customers demand a significant amount of target products, the industry generates the required capacity.

3. Strategy and structure index: It is obvious that firms are the natural and essential components of cluster; also, the performance of each firm is a function of the long-term strategies and plans of the companies.

4. Communication index of enterprises: In the industrial cluster, enterprises and economic and non-economic institutions form a group that cooperate horizontally and vertically, and compete with each other. It can be said that if cluster formation does not make it necessary to compete and cooperate at the regional, national or international level, the goal of forming and supporting a cluster has not been provided.

5. Infrastructure index: The importance of infrastructure in relation to economic performance, both at the enterprise level and at industry level, has been specified. A network of private and public local institutions that support economic agents and research centers, and universities that provide support is considered as an important factor in the study of industrial clusters.

6. Geographical concentration index: Since the emergence of the cluster concept, geographic concentration is one of the main cluster elements. The existence of natural resources, the reduction of transaction costs, the achievement of economies of scale due to mass production, and the ease of market specialization are some strong factors regarding the importance of geographical concentration in the creation of industrial clusters.

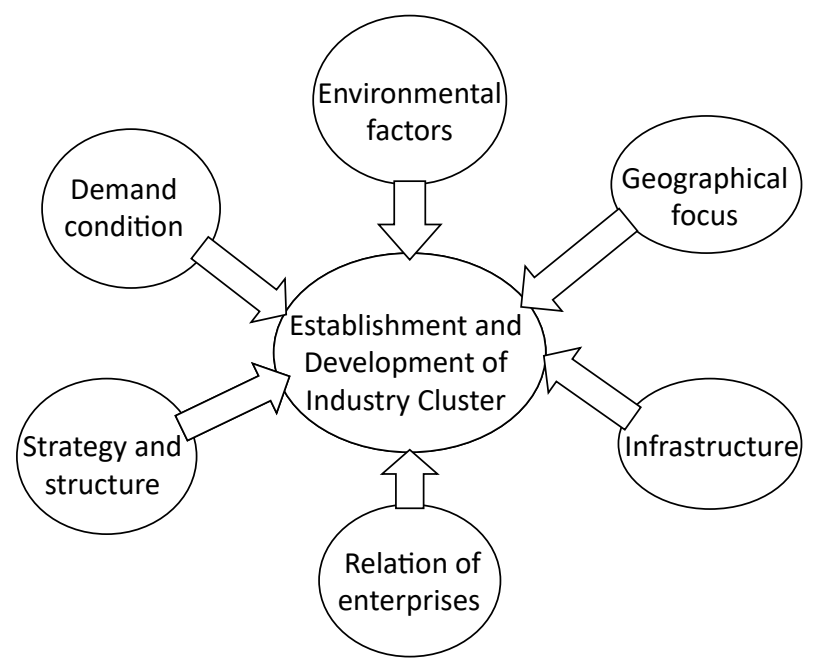

Figure 1. Factors affecting the development of industrial cluster of rail industries 
Table 1. Factors affecting the development of industrial cluster of rail industries

\begin{tabular}{|c|c|c|}
\hline Main factor & Sub-factors & Researcher \\
\hline \multirow{4}{*}{$\begin{array}{l}\text { Environmental } \\
\text { factors }\end{array}$} & Human resources & $\begin{array}{l}\text { Marshall, 1920; En- } \\
\text { right, } 2001\end{array}$ \\
\hline & Natural resources & $\begin{array}{l}\text { Porter, 1990; Enright, } \\
\text { 2001; Marshall, } 1920\end{array}$ \\
\hline & Fund & $\begin{array}{l}\text { Chiaroni and Chiesa, } \\
\text { 2006; Seeley, } 2011\end{array}$ \\
\hline & Technology & Seeley, 2011 \\
\hline \multirow{5}{*}{$\begin{array}{l}\text { Demand condi- } \\
\text { tions }\end{array}$} & $\begin{array}{l}\text { The size of domestic } \\
\text { and foreign markets }\end{array}$ & \multirow{5}{*}{$\begin{array}{l}\text { Enright, 2001; Porter, } \\
\text { 1990; Isbasoiu, 2007; } \\
\text { Porter, 1998; Seeley, } \\
2011\end{array}$} \\
\hline & $\begin{array}{l}\text { Distance from the } \\
\text { foreign market }\end{array}$ & \\
\hline & $\begin{array}{l}\text { The vision of do- } \\
\text { mestic and foreign } \\
\text { markets }\end{array}$ & \\
\hline & $\begin{array}{c}\text { Limitations and bar- } \\
\text { riers to be in foreign } \\
\text { market }\end{array}$ & \\
\hline & Native demand & \\
\hline \multirow{4}{*}{$\begin{array}{l}\text { Strategy and } \\
\text { structure }\end{array}$} & Ability to manage & $\begin{array}{l}\text { Chiaroni and Chiesa, } \\
2006\end{array}$ \\
\hline & $\begin{array}{l}\text { Corporate asset } \\
\text { structure }\end{array}$ & $\begin{array}{l}\text { Porter, 1990; Mullin } \\
\text { and Kotval,1998; Chiar- } \\
\text { oni and Chiesa, } 2009\end{array}$ \\
\hline & Corporate strategy & Rabulotti, 2004 \\
\hline & $\begin{array}{c}\text { External impacts on } \\
\text { industrial cluster } \\
\text { creation }\end{array}$ & Marshall, 1920 \\
\hline \multirow{3}{*}{$\begin{array}{l}\text { Relation of } \\
\text { enterprises }\end{array}$} & $\begin{array}{c}\text { Corporate co-oper- } \\
\text { ation }\end{array}$ & \multirow{3}{*}{$\begin{array}{l}\text { Jacobs and De Man, } \\
\text { 1996; Ketels, 2004; } \\
\text { Enright, 2001; Maskell, } \\
2001\end{array}$} \\
\hline & $\begin{array}{c}\text { Corporate compe- } \\
\text { tition } \\
\end{array}$ & \\
\hline & Information flow & \\
\hline \multirow{5}{*}{ Infrastructure } & $\begin{array}{l}\text { Backup industries } \\
\text { and suppliers }\end{array}$ & $\begin{array}{c}\text { Marshall, 1920; } \\
\text { Enright, 2001; Porter, } \\
\text { 1990; Isbasoiu, 2007; } \\
\text { Yamawaki, } 2002 \\
\end{array}$ \\
\hline & Institutions & \multirow{3}{*}{$\begin{array}{l}\text { Seeley, 2011; Chiaroni } \\
\text { and Chiesa, } 2006\end{array}$} \\
\hline & Industry policy & \\
\hline & Research centers & \\
\hline & $\begin{array}{l}\text { Communication } \\
\text { infrastructure and } \\
\text { transportation }\end{array}$ & Seeley, 2011 \\
\hline
\end{tabular}

\begin{tabular}{|c|c|c|}
\hline \multirow{7}{*}{$\begin{array}{c}\text { Geographical } \\
\text { concentration }\end{array}$} & $\begin{array}{c}\text { Small urban dimen- } \\
\text { sion }\end{array}$ & $\begin{array}{c}\text { Bagnasco and Trigilia, } \\
1984\end{array}$ \\
\cline { 2 - 3 } in the area & Sack of rival cluster & Seeley, 2011 \\
\cline { 2 - 3 } & $\begin{array}{c}\text { Specialization of } \\
\text { market factors }\end{array}$ & $\begin{array}{c}\text { Marshall, 1920; Chiar- } \\
\text { oni and Chiesa, 2006 }\end{array}$ \\
\cline { 2 - 3 } & $\begin{array}{c}\text { The presence of } \\
\text { leading companies } \\
\text { in the region }\end{array}$ & $\begin{array}{c}\text { Jacobs and De Man, } \\
\text { 1996; Isbasoiu, 2007 }\end{array}$ \\
\hline
\end{tabular}

\section{RESEARCH METHODOLOGY}

This is an applied study in terms of purpose and is a descriptive-survey research in terms of data gathering. In order to achieve the main objective of the research, comprehensive identification of the factors and sub-factors affecting the creation and development of industrial clusters, the Delphi method was used and it was moderated using statistical analysis and, in the end, the network analysis process technique was used to rank these factors. In the following, the research steps are described:

Step one: The Delphi team was selected with the help of the 10 members of an analyst team consisting of two researchers, five experts in the rail industry of the country and three industry experts from the Markazi Province. This group included 20 people including experts, faculty members of universities and executive forces in the rail industry in the Markazi Province. If there was no new proposal by arbiters or after realization of the $70 \%$ agreement between the arbiters, the Delphi round was ended. As both conditions were fulfilled in the third round, the Delphi rounds were ended and the list of six main indicators (factors) and the 26 sub-indicators (sub-factors) was presented as the final result of the research.

Step two: At this step, according to the data obtained from the Delphi method, and due to lots of the sub-factors of each factor, a prioritization questionnaire was distributed to modify the sub-factors of each of these six factors, because the development of the sub-factors of each criterion will make the completion of the pair questionnaire time-consuming and will increase the percentage of error in the completion of the questionnaire. The analysis unit in this study included industry cluster experts with a bachelor's degree, a master's degree and a Ph.D. degree in the fields of Transportation Engineering, Industrial Management, Business Administration, and Transportation Economics with over 5 years of experience. Also, in this research, the arbitration sampling method was used to determine the sample size. The factors (indicators) prioritization questionnaire was 
distributed among 60 people and 55 questionnaires were collected.

Step three: In this step, using the network analysis process technique, factors influencing the creation and development of industrial clusters in the rail industries were ranked. To this end, the relative importance of each factor was measured according to experts.

\section{Network analysis process}

The network analysis process was developed by Saaty and Takizova (1986), and it aims to structure the decision-making process according to a scenario influenced by multiple independent factors. This technique improves the hierarchy analysis process as a multi-criteria decision-making tool by replacing the network with the hierarchy. Since problem solving is investigated in the network approach, in which factors are similar to hierarchical issues, and there is only dependence among the sub-factors of the research, in this condition, the network can be divided into several sub-issues consisting of hierarchical levels so that each level contains a set of criteria related to each sub-issue (Jharkharia and Shankar, 2004).

\section{Validity and reliability of the questionnaire}

In this study, Cronbach's Alpha coefficient was used to measure the prioritization questionnaire and, according to the main factors of the research, six Cronbach's Alphas were obtained in relation to the six indices. The results are provided in Table 2.

Table 2. Cronbach's Alpha Coefficients of Research Indicators

\begin{tabular}{|c|c|}
\hline Index & $\begin{array}{c}\text { Cronbach's Alpha } \\
\text { Coefficient }\end{array}$ \\
\hline Environmental factors & 0.82 \\
\hline Demand conditions & 0.86 \\
\hline Strategy and Structure & 0.79 \\
\hline Communications between enterprises & 0.74 \\
\hline Infrastructure & 0.81 \\
\hline Geographic concentration & 0.79 \\
\hline
\end{tabular}

According to the results of the Cronbach's Alpha test, the coefficient of reliability of all factors is more than 0.7 and all the indicators are accepted.

\section{Data analysis}

In this part of the research, in order to prioritize the factors affecting the creation and development of industrial clusters in the Markazi Province, after adjusting the sub-factors of each of the comparison matrices of the main factors, the matrix of dependence of the main factors to each other and the dependence of the sub-factors of each factor are formed together and, finally, their compatibility is examined. In the following, these steps are described for the main factors in the environmental factors index. It should be noted that the primary pair-wise comparison matrix for the sub-factors of environmental factors index is obtained from the geometric mean of experts' opinions.

Table 3. Matrix of pair-wise comparisons of sub-factors of environmental factors

\begin{tabular}{|c|c|c|c|c|c|}
\hline & $\begin{array}{c}\text { Natural } \\
\text { resources }\end{array}$ & $\begin{array}{c}\text { Human } \\
\text { resources }\end{array}$ & $\begin{array}{c}\text { Capi- } \\
\text { tal }\end{array}$ & $\begin{array}{c}\text { Tech- } \\
\text { nology }\end{array}$ & $\begin{array}{c}\text { Eigen- } \\
\text { vector }\end{array}$ \\
\hline $\begin{array}{c}\text { Natural } \\
\text { resources }\end{array}$ & 1 & & 8.52 & 8.20 & 0.39 \\
\hline $\begin{array}{c}\text { Human } \\
\text { resources }\end{array}$ & 2.03 & 1 & 5.6 & 8.40 & 0.49 \\
\hline Capital & & & 1 & 2.18 & 0.07 \\
\hline $\begin{array}{c}\text { Technol- } \\
\text { ogy }\end{array}$ & & & & 1 & 0.05 \\
\hline Total & & & & & 1 \\
\hline
\end{tabular}

In the following, the normalized final matrix is calculated and the results are presented with the corresponding weight vector in Table 4.

Table 4. Final normalized matrix, pair-wise comparisons of subfactors of environmental factors index

\begin{tabular}{|c|c|c|c|c|c|}
\hline & $\begin{array}{c}\text { Natural } \\
\text { resources }\end{array}$ & $\begin{array}{c}\text { Human } \\
\text { resources }\end{array}$ & $\begin{array}{c}\text { Capi- } \\
\text { tal }\end{array}$ & $\begin{array}{c}\text { Tech- } \\
\text { nology }\end{array}$ & $\begin{array}{c}\text { Eigen- } \\
\text { vector }\end{array}$ \\
\hline $\begin{array}{c}\text { Natural } \\
\text { resources }\end{array}$ & 0.30 & 0.25 & 0.55 & 0.41 & 0.38 \\
\hline $\begin{array}{c}\text { Human } \\
\text { resources }\end{array}$ & 0.62 & 0.55 & 0.36 & 0.42 & 0.49 \\
\hline Capital & 0.04 & 0.10 & 0.07 & 0.11 & 0.08 \\
\hline $\begin{array}{c}\text { Technol- } \\
\text { ogy }\end{array}$ & 0.04 & 0.10 & 0.02 & 0.06 & 0.05 \\
\hline Total & & & & & 1 \\
\hline
\end{tabular}

In the end, by combining all of finite super-matrices, the result of the decision was determined and the relative importance of the criteria affecting the creation and development of industrial cluster industry in the Markazi Province was measured by a questionnaire and by the use of the opinions of the experts of the rail industry of the country and the Markazi Province. The final matrix of this study is presented in Table 5.

In Table 6 below, according to the values obtained for each of the factors and sub-factors, the ranking and prioritization of each of the sub-factors of the research are presented. 


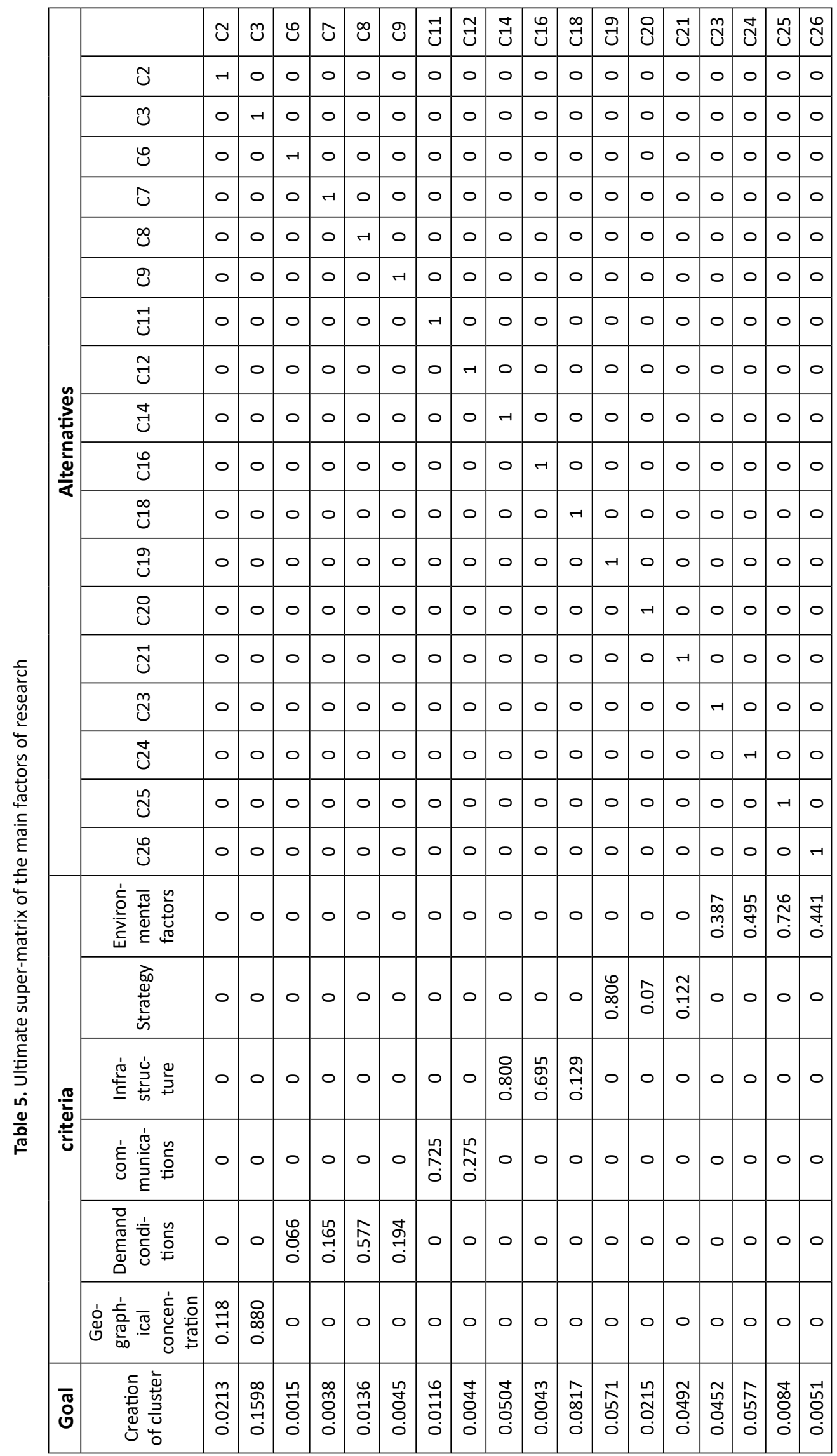


Table 6. Ranking of the sub-factors of the main research indicators

\begin{tabular}{|c|c|c|c|c|c|}
\hline $\begin{array}{l}\text { The values of } \\
\text { each indicator } \\
\text { relative to the } \\
\text { target }\end{array}$ & $\begin{array}{l}\text { The values of } \\
\text { each sub-index } \\
\text { relative to the } \\
\text { target }\end{array}$ & Priority & Sub-factors & Row & Indicator \\
\hline \multirow{2}{*}{$0.181264 C 6$} & 0.021391 & 7 & Lack of rival cluster in the area & $\mathrm{C} 2$ & \multirow{2}{*}{$\begin{array}{c}\text { Geographical concen } \\
\text { tration }\end{array}$} \\
\hline & 0.159873 & 1 & Costs resulting from mass production scale & $\mathrm{C} 3$ & \\
\hline \multirow{4}{*}{0.023573} & 0.001558 & 17 & The size of the domestic/foreign market & C6 & \multirow{4}{*}{ Demand conditions } \\
\hline & 0.003829 & 16 & Marketing & C7 & \\
\hline & 0.013617 & 8 & Commerce & C8 & \\
\hline & 0.004569 & 13 & Limitations and barriers to be in market & $\mathrm{C9}$ & \\
\hline \multirow{2}{*}{0.016079} & 0.011656 & 9 & Corporate co-operation & $\mathrm{C} 11$ & \multirow{2}{*}{ Communications } \\
\hline & 0.004423 & 14 & Corporate competition & $\mathrm{C} 12$ & \\
\hline \multirow{3}{*}{0.063052} & 0.050495 & 4 & Support industries \& Suppliers & C14 & \multirow{3}{*}{ Infrastructure } \\
\hline & 0.004386 & 15 & $\begin{array}{c}\text { Communication Infrastructure/Transportation of } \\
\text { institutions }\end{array}$ & $\mathrm{C} 16$ & \\
\hline & 0.008171 & 11 & Institutions & $\mathrm{C} 18$ & \\
\hline \multirow{3}{*}{0.078739} & 0.057164 & 3 & Ability to manage & $\mathrm{C} 19$ & \multirow{3}{*}{ Strategy/structure } \\
\hline & 0.021575 & 6 & Corporate asset structure & $\mathrm{C} 20$ & \\
\hline & 0.00000 & $*$ & Corporate strategy & $\mathrm{C} 21$ & \\
\hline \multirow{4}{*}{0.112916} & 0.045212 & 5 & Human resources & $\mathrm{C} 23$ & \multirow{4}{*}{$\begin{array}{l}\text { Environmental } \\
\text { factors }\end{array}$} \\
\hline & 0.057754 & 2 & Natural resources & $\mathrm{C} 24$ & \\
\hline & 0.008470 & 10 & Capital & $\mathrm{C} 25$ & \\
\hline & 0.008148 & 12 & Technology & $\mathrm{C} 26$ & \\
\hline
\end{tabular}

\section{DISCUSSION AND CONCLUSION}

According to the results, the geographic concentration index has been rated at 0.181264 , which shows its high importance, especially in terms of costs from the mass production scale with rank of 0.159873 . Since the concept of cluster was created, geographic concentration has been one of the main cluster elements. Bagnasco and Trigilia (1984), in their study have examined the importance of small urban dimension and spatial features. Historical clustering studies are reflected from the efforts of Alfred Marshall in 1920 to localize the economy. He referred the positive effects of putting together industries, which, in addition to facilitating the infrastructure facilities, it would also save the costs of the mass production scale. The lack of managerial and entrepreneurial skills of the owners of enterprises and the lack of clarity of the timing of implementation of development plans in the rail industry of the country and especially in the rail industry of the Markazi Province have caused financial weakness and lack of liquidity. According to his study, El-Juhany (2010) says that his lack of economic knowledge, the weakness of management experience, the inability to influence environmental change and high vulnerability from this perspective, and the limitation of funding in comparison with large companies, are the common problems of enterprises.
Mistrust and lack of financial clarity between manufacturing and distributing units and public sector agents, as well as the weakness of the culture of cooperation, have caused problems for creation trust among economic agents in the cluster of rail industries in the Markazi Province so that the resolution of this problem requires the development of culture and the introduction of widespread benefits of cooperation. In his research, Rabulotti (2004) referred a strong set of forward, backward, and horizontal links, and labor market relations based on market and non-market exchanges of goods, services, information, and individuals in the creation and development of industrial clusters.

\section{RESEARCH SUGGESTIONS}

If industrial clusters are created and developed in the region, it will have many benefits for the stakeholders, as the main reason for the development of industrial areas is the savings due to the accumulation of units. This is because there will be positive side effects in production and the production cost will be reduced due to the increase in the production of the other enterprises; thus, this issue is very important for the industrial cluster.

Since industrial production in the form of a cluster requires the cooperation and the positive competition of 
in-cluster enterprises, it is suggested that the communication and cooperation for key activities is required between the enterprises that are active in the rail industry, given the strong social and cultural background of the region, which is almost homogeneous and can link economic agents together; they should also use the key capabilities of each other; in addition, the cluster should be integrated into the global chain, as it brings together the economic attractions of enterprises, and ultimately enterprises earn more money.

It is suggested to create a kind of organizational structure called subcontractors and to gather other companies or units as a large corporation. Some of the benefits of this action are reduced transportation costs, improved marketing, and improved product quality; in addition, the contractor can lead the government to eliminate cumbersome regulations and facilitate the development of industrial clusters in the region. It is also suggested that this action be taken into consideration for discovering and using the regional advantages and networking and creation of synergies between in-cluster enterprises as strategic strategies in all major economic and industrial development policies of the country.

\section{REFERENCES}

Agakhani, R. (2009), "Development of Rail Industries Using the Industrial Cluster Development Model", in 2nd International Conference on Recent Advances in Railway Engineering, Iran, Tehran.

Altenburg, T.; Meyer-Stamer, J. (1999), "How to promote clusters: Policy experience from Latin America", World Development, Vol. 27, No. 9, pp. 1693-1713.

Bagnasco, A.; Trigilia, C. (eds.) (1984), Sodeta e politica nelle aree di piccolo impresa, Caso Valdesa, Arsenale, Venice.

Chiaroni, D.; Chiesa, V. (2006), "Forms of creation of industrial clusters in biotechnology", Technovation, Vol. 26, No. 9, pp. 1064-1076.

El-Juhany, L. I. (2010), “Degradation of Date Palm Trees and Date Production in Arab Countries: Causes and Potential Rehabilitation", Australian Journal of Basic and Applied Sciences, Vol. 4, No.8, pp. 3998-4010.

Enright, M. J. (2001), "Regional Clusters: What we Know and What We Should Know, Paper prepared for the Kiel Institute", Conference of European International Workshop on Innovation Clusters and Interregional Competition, 12-13 November, pp. 114-138.

Isbasoiu, G. (2007), "Industrial Clusters and Regional Development: The Case of Timisoara and Montebelluna".
Conference of European Regions Knowledge Based Innovation Network. Brussels, 10-11 May 2007.

Jacobs, D.; De Man, A. (1996), "Clusters, Industrial Policy and Firm Strategy", Technology Analysis and Strategic Management, Vol 8. No. 4, pp. 425-438.

Jharkharia, S.; Shankar, R. (2004), "Selection of Logistics Service Provider: An Analytic Network Process (ANP) Approach", Omega, Vol. 35, No. 3, pp. 274-289.

Ketels, C. H. M. (2004), Cluster-based economic development: What Have We Learned, Harvard Business School, Department of Trade and Industry, London, United Kingdom.

Kim, C. (2002), A Model Development for Measuring Global Competitiveness of the Tourism Industry in the Asia-Pacific Region, Korea Institute for International Economic Policy, Sejong, South Korea.

Kuah A. T. H (2002), "Cluster Theory and Practice: Advantages for the Small Business Locating in a Vibrant Cluster", Journal of Research in Marketing and Entrepreneurship, Vol. 4, No. 3, pp. 206-228.

Kumar, S. (2005), Development of Industrial Cluster, Munich Personal RePEc Archive, Paper No. 171.

Mansouri, A. (2008), Introduction to industrial cluster: A brief overview on the definition and characteristics of industrial clusters, Publications of Public and International Relations of Small Industries Organization and Industrial Towns of Iran, Tehran.

Marshall, A. (1890), Principles of Economics, Macmillan, London.

Marshall, A. (1920), Principles of Economics, 8th ed. Macmillan, London.

Maskell, P. (2001), "Towards a knowledge-based theory of the geographical cluster", Journal of Industrial and Corporate change, Vol. 10, No. 4, pp. 921-943.

Mullin J. R.; Kotval, Z. (1998), "The potential for planning an Industrial Cluster in Barre, Vermont: a case of 'hard rock' resistance in the granite industry", Planning Practice \& Research, Vol. 13, No. 3, pp. 311-318.

Porter, M. E. (1990), The Competitive Advantage of Nations, Basic Books, New York.

Porter, M. E. (1998), Clusters and the New Economic of Competition, Harvard Business Review, Nov./Dec.

Rabulotti, R. (2004), Industrial clusters of the successful model of the endogenous development, Rasa Publication, Tehran.

Saaty, T. L.; Takizawa, M. (1986), “Dependence and Independence: From Linear Hierarchies to Nonlinear Net- 
works", European Journal of Operational Research, Vol. 26, No. 2, pp. 229-237.

Seeley,E.L. (2011), “A New View on Management Decisions that Lead to Locating Facilities in Industrial Clusters", The Journal of Business Inquiry, Vol. 10, No.1, pp. 81-94.

Stimson, R. J.; Stough, R. R.; Roberts, B. H. (2006),

Regional Economic Development: Analysis and Planning
Strategy, 2th ed., Springer-Verlag Berlin Heidelberg, Heidelberg, Germany.

Yamawaki, H. (2002), "The Evolution and Structure of Industrial Cluster in Japan", Small Business Economics, Vol. 18, No 1-3, pp. 121-140.

Received: 16 May 2018

Approved: 12 Sep 2018

DOI: 10.14488/BJOPM.2018.v15.n4.a3

How to cite: Rahmani, K.; Yadegari, R.; Khiyabani, F. M. (2018), "Identification and Prioritization of the Effective Factors on the Creation and Development of Industry Cluster of Rail Industries in Markazi Province Using Network Analysis Technique", Brazilian Journal of Operations \& Production Management, Vol. 15, No. 4, pp. 490-498, available from: https://bjopm.emnuvens.com.br/bjopm/article/view/493 (access year month day). 